\title{
Evidences that the Infection with Hepatitis A Virus (HAV) might Protect Against Hepatitis C Virus and the Other Types
}

\author{
Amro Abd Al Fattah Amara* \\ Protein Research Department, Genetic Engineering and Biotechnology Research Institute, Egypt \\ *Corresponding author: Amro Abd Al Fattah Amara, Protein Research Department, Genetic Engineering and \\ Biotechnology Research Institute, City for Scientific Research and Technological Applications, Alexandria, Egypt
}

\begin{tabular}{|c|c|}
\hline ARTICLE INFO & ABSTRACT \\
\hline Received: 栔 April 16, 2019 & Citation: Amro Abd Al Fattah Amara. Evidences that the Infection with Hepatitis A Virus \\
\hline Published: 幽 April 25, 2019 & $\begin{array}{l}\text { (HAV) might Protect Against Hepatitis C Virus and the Other Types. Biomed J Sci \& Tech } \\
\text { Res 17(3)-2019. BJSTR. MS.ID.003007. }\end{array}$ \\
\hline
\end{tabular}

\section{Dear Editor}

The hepatitis viruses are viruses that infect the liver. They are mainly five unrelated hepatotropic viruses; hepatitis A, B, C, D, and E. Those five types are genetically closed to each other. They can be classified regarding to their genomic material and types as Picornavirus (+ssRNA), Orthohepadnavirus (dsDNART), Hepacivirus (+ssRNA), Deltavirus (-ssRNA), and Hepevirus (+ssRNA). I have personally gotten the hepatitis A virus during my adolescent. Being healthy attracts my attention that the infection with virus's hepatitis A virus might protect against the hepatitis $C$ virus. During the last ten years, I have asked everybody who gained hepatitis A virus if he/she gained hepatitis $C$ virus and the response was always no.

I want to attract your kind attention and the attention of the scientific community that there is an evidence that the infection with hepatitis A virus (HAV) might protect against Hepatitis C virus and the other types.

As a scientist, to prove that, taking serum from the hepatitis A virus to inactivate, precipitate or do hemagglutination test will prove nothing because of the difference between the in vivo and the in vitro results.

I am interested through your respective journal to attract the attention of the scientific community to target this observation through worldwide statistical analysis for the relationship between hepatitis A virus infected patients and the \% of other types of infection with hepatitis viruses.
ISSN: 2574-1241

DOI: 10.26717/BJSTR.2019.17.003007

Amro Abd Al Fattah Amara. Biomed J Sci \& Tech Res

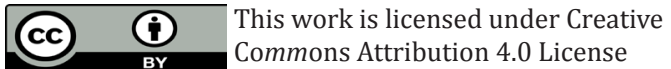

Submission Link: https://biomedres.us/submit-manuscript.php

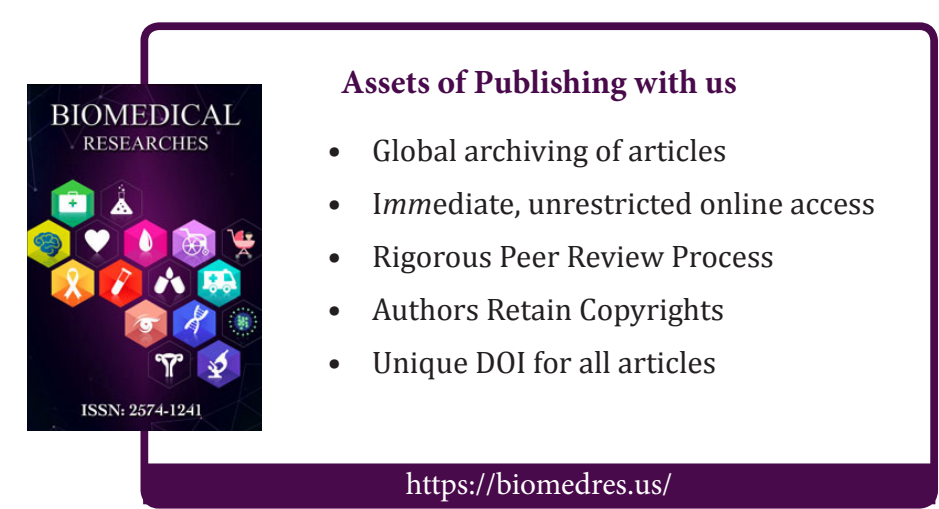

